\title{
Disease Diagnosis Prevention and Control of Diseases in L. vannamei
}

\author{
T. Suguna* \\ Fisheries Research Station, S.V. Veterinary University, West Godavari, \\ Andhra Pradesh - 534 199, India \\ *Corresponding author
}

\section{A B S T R A C T}

\begin{tabular}{|c|}
\hline Keywords \\
\hline $\begin{array}{l}\text { L. Vananmei, } \\
\text { Diseases, Disease } \\
\text { causing agents, } \\
\text { Preliminary } \\
\text { knowledge, } \\
\text { Preventive } \\
\text { measures }\end{array}$ \\
\hline Article Info \\
\hline $\begin{array}{l}\text { Accepted: } \\
07 \text { August } 2020 \\
\text { Available Online: } \\
10 \text { September } 2020\end{array}$ \\
\hline
\end{tabular}

Keywords

L. Vananmei, Diseases, Disease Preliminary knowledge, Preventive measures

\section{Introduction}

In Aquaculture, especially shrimp farming, has witnessed tremendous growth in the last several years, and this has been achieved through expansion, intensification and diversification. Like in other shrimp growing countries, major transformation in shrimp production has been witnessed in India, after switching over from native species, Penaeus monodon to the non-native species, whiteleg shrimp, Penaeus vannamei which was introduced during 2009-10. Ever since the introduction of $P$. vannamei, the area under farming as well as the production have increased remarkably. According to MPEDA (2015), farming area has increased from 283 ha in 2009-10 to 50,241 ha in 2014-15 and the production has also grown from 1731 to 353,413 metric tonnes. However, as happened in the case of $P$. monodon, $P$. vannamei farming also has been experiencing largescale production losses due to a variety of diseases. These diseases have been either due to infectious aetiology, poor management measures, spurious seed, water pollution. Diseases are the outcome of imbalance between environment, host and pathogen. The impact of disease is a combination of several factors such as mass mortality of shrimp, 
reduction in feed acceptance or morbidity. Morbidity and production losses due to multiple disease conditions of obscure aetiology have been a common phenomenon and running mortality syndrome (RMS), slow growth / retarded growth caused by multiple causes, white gut and white faeces syndrome and vibriosis etc. have been of common occurrence. Although shrimp farming in the neighboring Asian countries and Latin America have been severely affected by Acute Hepato Pancreatic Necrosis Disease (AHPND), popularly known as Early Mortality Syndrome (EMS), Indian shrimp farming system has not been affected by this serious problem.

Concomitant with the expansion and intensification of shrimp aquaculture, large number of diseases, especially those caused by viral infection, have been recorded in farmed shrimp. Disease such as white spot syndrome virus (WSSV) has devastated the shrimp aquaculture world over due to its high virulence, wide host and geographical range. Some of the other serious viral diseases include Taura Syndrome Virus (TSV), Yellow Head Virus (YHV), infectious hypodermal and haematopoietic necrosis virus (IHHNV), infectious myonecrosis virus (IMNV) etc., In addition, a number of pathogens or disease conditions have emerged in farmed shrimp during the past several years and caused significant production loss to the industry. Further, some of the existing / endemic diseases have shown increased virulence and a few of them also showed distribution in new host species and geographical areas. Some of the reasons attributed to these phenomena include high intensification of culture practices, introduction of non-native species for farming, unregulated transboundary movement of aquatic animals and products together with changing climate and the increased stress imposed on the farmed animals. Although many pathogens results in heavy mortality in farmed shrimp, some of the emerging disease conditions which are reported recently resulted in severe retarded growth or other chronic conditions. Nevertheless, these chronic conditions are often resulted in heavy production losses and significant economic impact in shrimp farming.

\section{Emerging diseases}

Globally, disease emergence is recognized as an important constraint to the expansion of aquaculture. An "emerging disease" is defined as a new disease, a new presentation of a known disease or an existing disease that appears in a new geographical area (Brown, 2000). According to Walker and Winton (2010), emerging disease can be categorized into four: 'i) new or previously unknown diseases; ii) known diseases appearing for the first time in a new species (expanding host range); iii) known diseases appearing for the first time in a new location (expanding geographical range); and iv) known diseases with a new presentation (different signs) or higher virulence due to changes in the causative agent'. Further, Walker and Winton reported that emerging new diseases are challenging problems because of the following reasons: 'a) difficulty or delay in developing confirmatory diagnostic tools; b) poor knowledge on the host susceptibility and host-range; c) lack of knowledge on the epidemiological factors such as mode of transmission, reservoirs and carrier hosts etc'. Following are some of the diseases which can be categorized under emerging diseases in farmed shrimp.

\section{White Spot Syndrome (WSD)}

White Spot Syndrome disease is the most serious threat faced by the shrimp farming industry worldwide. It was first reported in 
farmed $P$. japanicus from Japan 1992 - 93 and later identified in all shrimp farming countries. The WSSV can infect a wide range of aquatic crustaceans including marine, brackish and freshwater penaeids, crabs and cray fish. All decopod crustaceans including crabs, cray fish, freshwater prawns, spriny labsters and clawed labsters in marine brackish and freshwater sources are susceptible but morbidity and mortality as a consequence of infection is highly variable. Penaeid shrimps are highly susceptible to infection, often resulting in high mortality. Prevalence of WSSV is reported as highly valuable, from $<1 \%$ in infected wild populations to up to $100 \%$ in captive populations. It is caused by a double standard DNA virus. It damages the stomach, gills, antennal gland, heart and eyes. Affected shrimp are lethargic, show reddish body discoloration during advanced stage of disease. WSD is diagnosed by presence of characteristic white spots and rapid mortalities (Fig. 1). WSSV can be detected using polymerase chain reaction (PCR). It is transmitted vertically and horizontally by cannibalism, predation and by water borne routs. There is no treatment for WSSV except to take preventive measures, not to enter in the culture system. So filter and sanitise the pond water before stocking and follow good management practices and strict biodiversity measures to avoid the entry of disease in culture.

\section{Hepatopancreatic microsporidiosis (HPM)}

Hepatopancreatic microsporidiosis, caused by the microsporidian parasite, Enterocytozoon hepatopenaei (EHP), is an emerging pathogen of cultured penaeid shrimp. Incidence of EHP has been reported from cultured shrimps of many Southeast Asian Countries including Vietnam, Thailand, Malaysia, Indonesia and China. Recently, the pathogen has been recorded in the farmed shrimp in India
(Rajendran et al., 2016). EHP is reported to be associated with growth retardation in farmed shrimp. It was first discovered from Penaeus monodon in Thailand in 2004 (Chayaburakul, et al., 2004), and reported as an undersigned microsporidian. Subsequently, the parasite was identified and characterized from P. monodon from Thailand in 2009. It infects only the epithelial cells of the hepatopancreatic (HP) tubules of shrimp. The EHP infection affects the digestive and absorptive functioning of the hepatopancreas leading to poor growth and immunity (Fig. 2). Although there are reports indicating that EHP would cause growth retardation in farmed shrimp, a statistical correlation between the parasite and the clinical signs has not been proved so far. However, the parasite will not cause any mortality or obvious clinical signs and symptom. Nevertheless, the micropsoridian had been identified as one the pathogenic agents associated with white faces sysndrome (WFS) in cultured P. monodon in Vietnam. Similar indications have also been reported from Thailand.

EHP could not transmitted directly from shrimp by the oral (horizontal) route (Tangprasittipap et al., 2013). Clinical signs of EHP infection are not specific. The EHP spores can be detected by light microscopy in tissue sections or in squash preparation of hepatopencreas using specific vital stains. EHP spores could be reported from faecal matter of shrimp exhibiting white faeces syndrome (WFS) also (Tang et al., 2015); Rajendran et al., 2016). Other reported diagnostic methods include histopathology, in situ hybridization, polymerase chain reaction (PCR), loop - mediated isothermal amplification (LAMP) and real-time PCR (Suebsing et al., 2013a; Tangprasittipap et al., 2013; Tang et al., 2015; Liu et al., 2015).

Though it does not cause mortality, but limits growth and production finally resulting in 
economic loss. Complete drying of pond bottom can limit the spores, stock should be PCR tested and follow strict biosecurity measures as prevention.

Early Mortality Syndrome (EMS) / Acute hepatopancreatic necrosis Syndrome or disease (AHPNS or AHPND)

Recently, a new emerging disease known as Early Mortality Syndrome (EMS) or Acute Hepatopancreatic Necrosis Disease (AHPND), has been a major issue of concern for economic loss in the shrimp farming industry in many Asian countries and Latin America. Incidence of AHPND has been reported from China in 2010 and subsequently in Vietnam, Thailand, Malaysia and Mexico (Tran et al., 2013; Soto Rodriguex et al., 2015). However, there are no confirmed reports of EMS from India. It affects both Penaeus monodon and $P$. vannamei ( $P$. chinensis was also reported to be affected in China). The EMS / AHPND disease typically affect shrimp post larvae within 20-30 days after stocking and frequently causes up to $100 \%$ mortality. Recently, the i8.paraharmolyticus that is infected by a phage, which causes it to release a potent toxin (Lightner, 2014). Gross clinical signs of the disease include lethargy, slow growth, corkscrew swimming, loose shells and pale colouration. Other signs include an empty stomach and midgut, and a pale to white atrophied hepatopancreas, and ultimately dead animals can be seen at the bottom of the pond. The most distinctive histological feature of AHPND is extensive rounding and sloughing of hepatopancreatic tubule epithelial cells in the absence of any detected causative pathogen (Tran et al., 2013).

It has been reported that the AHPND V. parahaemolyticus strains possessed a unique plasmid called pVPA3-1, containing insecticidal related genes PirA and Pir B (Lightner 2014), and these genes have been used for diagnosing AHPND by PCR methods (Flegel and Lo, 2014; Flegel, 2014). Recently, a loop-meditated isothermal amplification (LAMP) method to detect AHPND has been developed (Koiwai et al., 2015).

AHPND can be prevented by use of SPF broodstock and restrict adoption of BMPS in hatcheries and grow out farms. Its horizontal transfer can be reduced by disinfection during pond preparation. Pond sludge management is also an importance strategy along with good management practices.

\section{Infectious myonecrosis (IMN)}

Outbreaks of infectious myonecrosis (IMN) due to infectious myonecrosis virus (IMNV) were first reported from Brazil in whiteleg shrimp, Penaeus vannamei, in 2002. Infectious myonecrosis disease is characterized by extensive necrosis of skeletal muscle, especially in the distal abdominal segments and tail fin. This disease resulted in cumulative mortality rate of up to $70 \%$ throughout the production cycle. The species of shrimp $P$. vannamei, $P$. stylirostris and $P$. monodon are susceptible to IMNV and among these species $P$. vannamei is the most susceptible. IMNV has been reported to be transmitted from shrimp to shrimp by cannibalism. Transmission via water and vertical transmission from broodstock to progeny probably occurs. The causative agent has been identified as an RNA virus known as infectious myonecrosis virus (IMNV), belonging to the Totiviridae family. Severely infected shrimp become lethargic during or after stressful events such as capturing using cast-netting, feeding, sudden changes in temperature and drop in salinity. However, shrimp will have full gut. In acute infection, animals show extensive whitish necrosis in 
skeletal muscles, especially in the distal abdominal segments and tail (Fig. 3). Lymphoid organ shows excessive hypertrophy. Necrotic areas may appear reddened similar to the color of cooked shrimp in some animals. Severe infection results in morbidity and high mortality which continues for several days. Juveniles and sub adults of $L$. vannamei farmed in marine or low saline, brackish water, appear to be the most severely affected by IMNV disease. The principal target tissue for IMNV includes the striated muscle, connective tissue, haemocytes and lymphoid organs. There is no reported treatment for IMNV. Stock should be PCR tested and seed should be of SPF quality. Good Management Practices proven to be the most successful method to control the disease.

Current diagnostic methods for the detection of IMNV range from clinical observation and histological examination (Poulos et al., 2006; da Silva et al; 2010) to molecular approaches. Molecular diagnosis include in situ hybridization using IMNV - specific gene probes (Tang et al., 2005). Molecular diagnostic methods reported include RT-PCR and nested RT-PCR (Poulos and Lightner, 2006; Senapin et al., 2007), quantitative real time RT-PCR (Andrate et al., 2007), and reverse-transcriptase loop-mediated isothermal amplication reaction (RT-LAMP; Puthawibool et al., 2009; Andrade and lightner, 2009). Apart from these, monoclonal antibiotics have been developed for detecting major capsid proteins of IMNV (Seibert et al., 2010). Moreover, an immunichromatographic strip test has been developed for the rapid diagnosis of IMNV (Chaivisuthangkura et al., 2013).

\section{Infectious Hypodermal and Haematopoietic Necrosis Virus (IHHNV)}

It was first discovered in $P$. vanname $i$ and $P$. stylirostris in America in 1981. Recent studies have revealed geographic variations in infectious hypodermal and harmatopoietic necrosis virus. It is caused by a small single standard DNA - containing parvovirus. The gross signs of disease are not specific to IHHNV. But included reduced feeding, elevated morbidity and mortality rates, fouling by epicommonsals and bluish body coloration.

In L. vannamei IHHNV cause runt deformity syndrome (RDS) which is growth retarded disease. Along with this, infected shrimp show change in color, deformed culture, rostrum, winkled antennal flagella, cuticular roughness, deformities in cuticular, thoragic and abdominal areas of exoskeleton (Fig. 4). Reduced feed consumption change in behaviour and appearance are also noticed. There is no treatment for this viral disease. As a preventive measure, the ponds should be dried between two crops, stock should be PCR tests, seed of SPF quality, strict biosecurity and good management practices have to be followed.

\section{Muscle necrosis of Penaeus vannamei caused by Penaeus vannamei nodavirus (PvNV)}

Viral muscle necrosis is an emerging disease of Penaeus (Litopenaeus) vannamei caused by Penaeus vannamei nodavirus (PvNV). The disease was first reported in Belize in 2004 and caused $50 \%$ production losses in affected shrimp ponds (Tang et al., 2007). PvNV is a member of the family Nodaviridae and genus Alphanodavirus (Tang et al., 2011). Infected shrimp show clinical signs of white, opaque lesions in the tail muscle thus resembling infectious myonecrosis virus (IMNV) infection. Histopathological changes include multifocal necrosis and haemocytic fibrosis in the skeletal muscle. Basophilic cytoplasmic inclusions in strained muscle, lymphboid organ and connective tissues are also 
observed. The disease also causes lymphoid organ spheroids. Although the virus does not cause serious mortality, the infection impacts survival in grow-out ponds. Sporadic mortality of infected shrimp has been recorded when they are under environmental stress such as crowding (stocking density $(>50 \mathrm{~m}-2)$ and high temperature $\left(>32^{\circ} \mathrm{C}\right)$ and survival decreased to $40 \%$ and increased food conversion ratio. The disease has not been reported from India.

Molecular techniques such as in situ hybridication and nested RT-PCR method have been developed for the detection of PvNV (Tang et al., 2017). Recently, reverse transcription loop mediated isothermal amplification (RT-LAMP) combined with colorimetric gold nanoparticles(AuNP) probe assay for visual detection of PvNV has been developed (Suebsing et al., 2013b). PvNV could be detected in mosquito fish, seabird feces, barnacles, and zooplankton by RTPCR, indicating their role as carriers of PvNV. This disease also has not been reported from India. The stock should be PCR tested and seed should be of SPF quality. Good management practices are the remedied measures.

\section{Running mortality syndrome (RMS)}

The term running mortality syndrome (RMS) has been used to describe prolonged chronic mortality during a crop. The mortality starts 1-2 months after stocking and become severe during later part of summer crop. This condition has been noticed in farmed $P$. vannamei in India, since 2001. The farmed shrimp in the affected ponds showed different mortality patterns which are result of unusual symptoms with no correlation to any other reported diseases. Reports indicate that some farmers have lost up to four crops, with mortality percentage reaching $50-70 \%$ in the most the cases (Fig. 5). The exact cause of the disease has not been identified; however, reports indicate the involvement of multiple causes such as covert mortality disease caused by covert mortality nodavirus (CMNV), white muscle syndrome, white gut / faeces syndrome and white patch disease.

The dead and moribund shrimp are found every day. The redding of appendage, tail and white abdomen muscle are symptoms of disease. Measures to be taken in selection of seed quality and follow strict biosecurity and good management practices.

\section{White gut / faeces syndrome (WFS)}

This has been observed in farmed P. monodn and $P$. vannamei. Gross signs of WFS in shrimp include the appearance of faecal string-like bodies in the gut. It appears like vermiform bodies that resemble gregarines within the hepatopancreatic tubules, at the hepatopancreas- stomach - midgut junction and in the midgut (Fig. 6). It generally occurs approximately from 2 months of culture and initially the causative agent has been reported as gregarines and the condition is described as white faeces syndrome (WS). The disease has been reported to cause $10-15 \%$ production loss due to decreased survival and smaller harvest size of shrimp. Although the causative organisms has not been identified, latest report shows that WFS arises from transformation, sloughing and aggregation of hepatopancreatic microvilli into vermiform bodies, which superficially resembles like with protozoan, gregarines (Sriurairatana et al., 2014) and this will result in retarded growth and may predispose shrimp to opportunistic pathogens. Vibrio species have been found in the faecal analysis from infected shrimps. Incidence of WFS in shrimp has been reported to be associated with stressful conditions including high stocking densities, poor water quality, poor pond bottom, high plankton blooms and bad feed 
management and high pollution in pond water. White faeces syndrome has been reported to be a serious problem in $P$. vannamei culture ponds of Andhra Pradesh and Tamilnadu (Mastan, 2015). Although direct correlation between the microsporidian
EHP and WFS has not been established, spores of the microsporidian have been recorded in the faecal samples of WFS infected / slow growing shrimp (Rahendran et al., 2016; Tang et al., 2016).

Fig.1 White spot disease

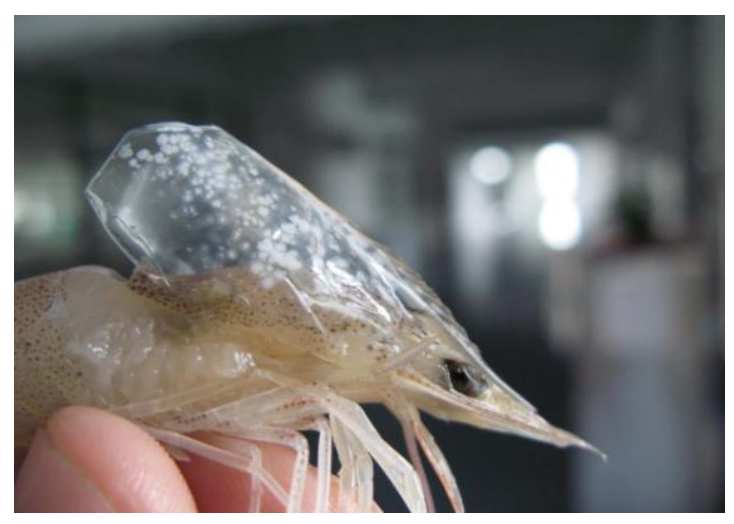

Fig.2 $L$. vannamei effected with growth retrodation and there by showing wide range of size variation due to Hepatopancreatic microsporidiosis

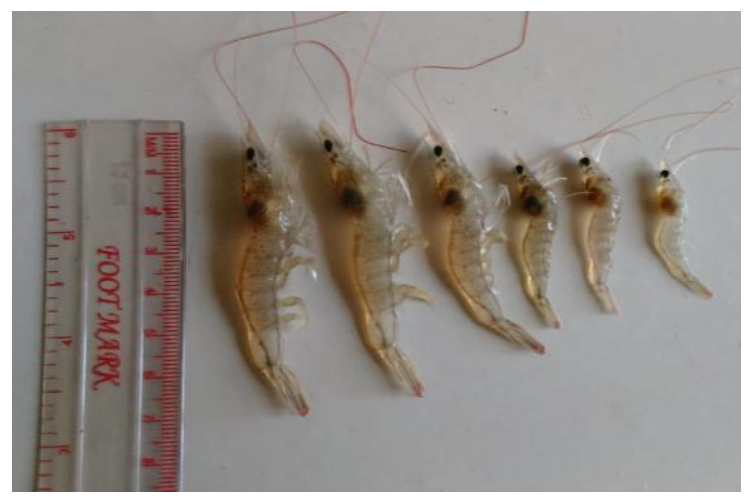

Fig.3

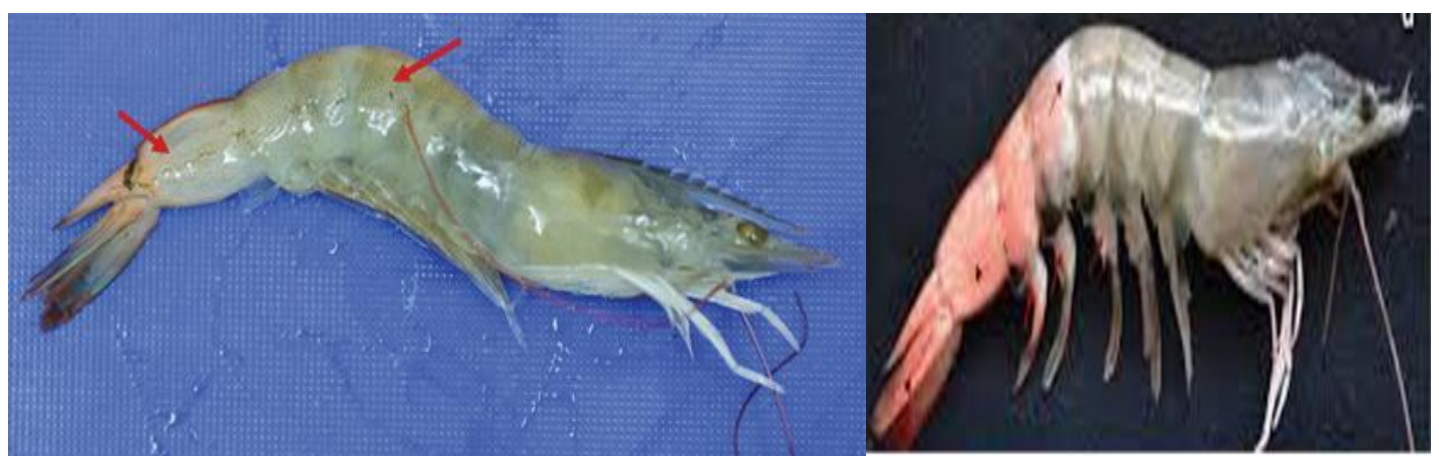


Fig.4

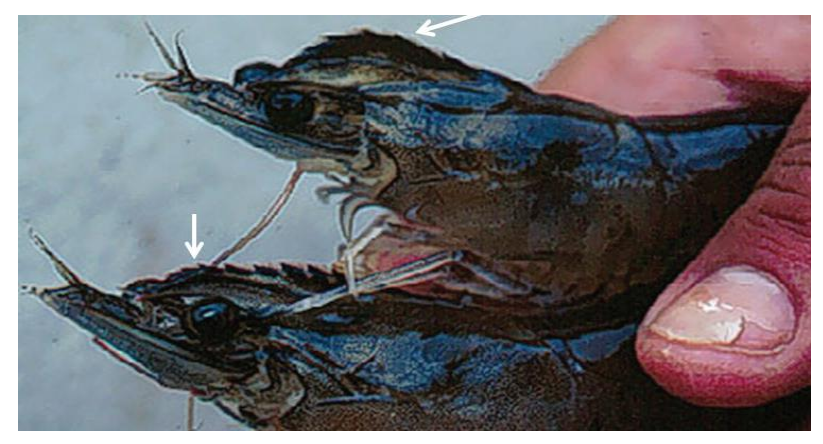

Fig.5

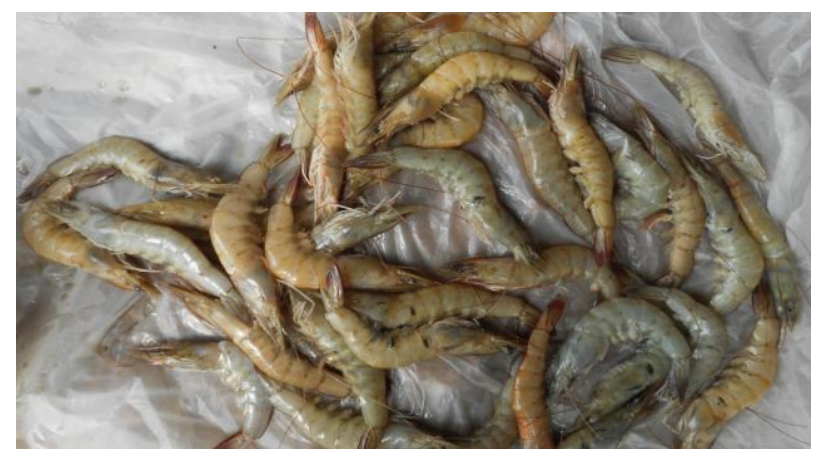

Fig.6 White gut / faeces syndrome
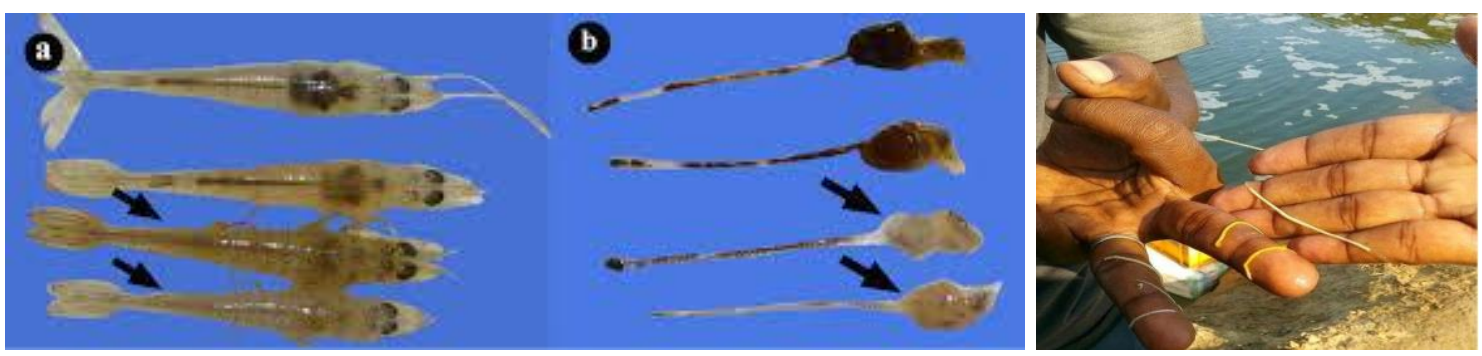

Fig.7

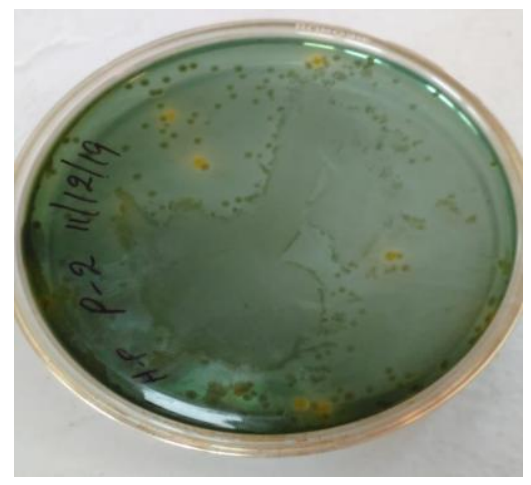




\section{Fig.8}

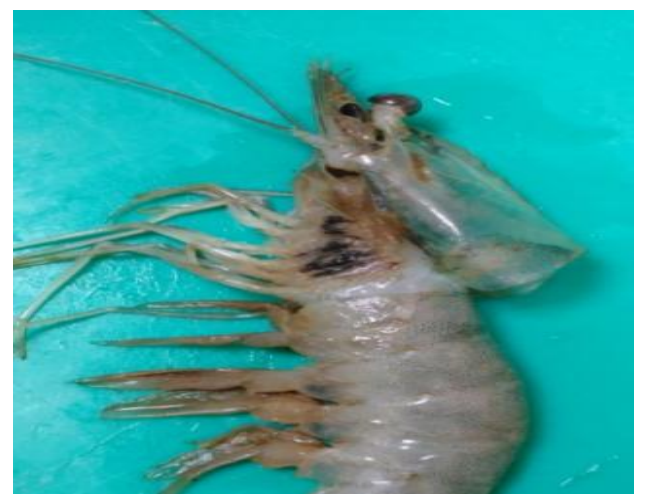

Fig.9

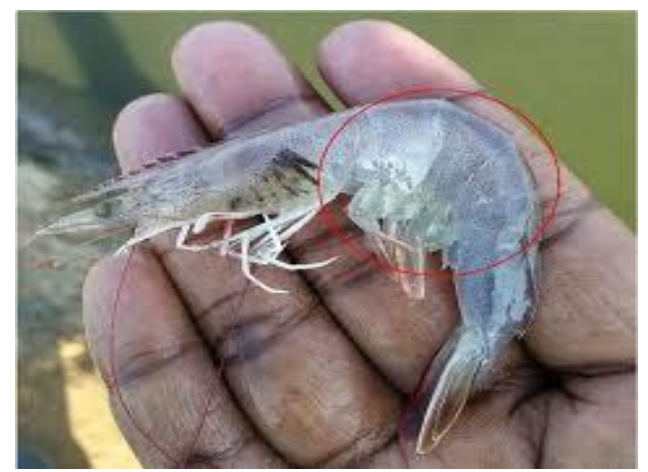

The disease can cause moderate to severe economic loss by reducing the shrimp survival by $20-30 \%$. The cause of white faces syndrome and treatment is uncertain. However reduced stocking density, proper water exchange together with better management practices will be helpful in evading WFS.

\section{White patch disease}

This condition has been witnessed in the semi-intensive $P$. vannamei farming in Andhra Pradesh and Tamilnadu. Initially (before 2012), the outbreak was observed in summer season only, however, in 2014, the disease outbreak could be noticed both in the winter and summer seasons also (Velmurugan et al., 2015). The major symptoms include focal to extensive necrotic areas in striated tail muscle tissues and abdominal muscles tissues.
Necrotic areas appear white opaque patches and in later stage the white patches changed into black spot or splinter. Other symptoms include whitish blue discoloration of infected shrimp body, loss of appetite, roughness on whole surface of infected shrimp with or without red discoloration and pale white muscles. The mortality rate was observed up to $70 \%$. The causative agent responsible for this condition has been identified as Grampositive bacterium, Bacillus cereus. The isolates exhibited high degree of proteolytic, haemolytic and lipase activity sufficient to lyse the cuticle of shrimp.

\section{Vibriosis}

The prevalence of Vibrio parahaemolyticus and $V$. harveyi has caused the occurrence of vibriosis and resulted in severe crop losses to the farmers. It easily affects the shrimp 
cultured in saline waters and known as "bacterial septicaemia". The shrimp are affected at any stage. Environmental stress aggrevate the disease and cause huge loss to farmers.

The major symptoms include the exhibition of septicaemia conditions followed by loss of reflex and cuticular fouling. The gills appear brown in color and the body becomes red. Antennal cut is also been observed. The affected shrimps do not eat and hence stomach appears empty and at times white watery liquid oozes out sometimes luminescence also been observed in ponds.

In serious conditions mortality is observed. Blackening or whitening of the basal part of the antenna, the oviduct and edges of the abdominal segments. The shrimps may exhibit either one of the symptoms or all the symptoms based on disease severity. The preventive measures like drying between production cycles, strict biosecurity measures and good management practices are to be adopted (Fig. 7).

\section{Black Gill Disease}

Affected shrimps have gills with black to brown discoloration, in acute cases necrosis and atrophy of the gill lamualle may be apparent. Blackening is due to the deposition of melanin at sites of massive haemocyte accumulation, followed by dysfunction and destruction of gill processes. A small percentage of shrimp population in ponds occasionally suffer with black gill disease. But in recent vannamei crops, incidence of black gill disease is in rise. The accumulation of organic load, feed wastage leads to the formation of toxic gases like ammonia, nitrite and hydrogen sulphide are the main causative factors for this disease. Sometimes vibrio bacteria may also pose blackening of gills in shrimp. Low DO levels in pond waters associated with black gill cause mortality in ponds. The gills become black in colour and the shrimp swims on the surface of pond (Fig. 8). In low DO ponds mortality is notices. Regular monitoring of water quality parameters, bacterial load and following good management practices are the preventive measures.

\section{Loose Shell Syndrome (LSS)}

Loose shell syndrome is a chronic, non infectious disease in shrimp which cause serious threat to farmers. Due to loose shell syndrome the feed conversion efficiency of shrimp substantially declines, leading to poor meat quality and doesn't fetch price. Affected ponds suffer poor survival and chronic mortalities. Stress factors like plankton crash, water quality and weather changes, the aged ponds with high organic load, high densities, toxic gases like ammonia and nitrite are prone to loose shell disease.

The affected shrimp has a paper like carapace with a gap between muscle tissue and exoskeleton (Fig. 9). They become sluggish and the growth retards. Regular drying of ponds between two crops, monitoring of water quality and following good management practices are preventive measures.

In conclusion it is extremely difficult to control disease once it strikes. Hence prevention is always better than cure. Disease prevention largely depends on the implementation of biosecurity measures and best management practices in the farms, disinfection, drying, removing the accumulated organic matter, tilling, liming, management of feed, water quality parameters and aquatic animal health management and further responsible farming results in a successful growth, production and enhanced economic status and simultaneously sustainability of culture. 


\section{References}

Andrade, T.P., Lightner, D.V. 2009. Development of a method for the direction of infectious myonecrosis virus by revere-transcription loopmediated isothermal amplification and nucleic acid lateral flow hybrid assay. J.Fish. Dis. 32, 911-924.

Andrade, T.P.D., Srisuvan, T., Tang, K.F.J., Lightner, D.V. 2007. Real-time revere transcription polymerase chain reaction assay using TaqMan probe for detection and quantification of infectious myonecrosis virus (IMNV). Aquaculture 264, 9-15.

Brown, C. 2000. Emerging diseases of animals - an overview. In: Brown, C., Bolin, C. (Eds.), Emerging Diseases of Animals. American Society for Microbiology, p. 324.

Chaivisuthangkura, P., Senapin, S., Wangman, P., Longyant, S., Sithigorngul, P. 2013. Simple and rapid detection of infectious myonecrosis virus using an immunochromatographic strip test Arch. Virol. 158, 1925-1930.

Chayaburakul, K., Nash, G., Pratanpipat, P., Sriurairatana, S., Withyachumnarnkul, B., 2004. Multiple pathogens found in growth-retarded black tiger shrimp Penaeus monodon cultivated in Thailand. Dis. Aquat. Org. 60, 89-96.

Da Silva, V.A., dos Santos, F.L., Bezerra, S.S., Pedrosa, V.F., Mends, P.D., Mendes, E.S. 2010. A multi-season survey for infectious myonecrosis in farmed shrimp, Litopenaeus vannamei, in Pernambuco, Brazil. J. Invertebr. Pathol. 104, 161-165.

Flegel, T.W. 2014. A game changer for the future development of aquaculture. 9th symposium on diseases in Asian Aquaculture, Ho Chi Minh City, Vietnam.
Flegel, T.W., Lo, C.F. 2014. Interim primers for specific detection of bacterial isolates that cause acute hepatopancreatic necrosis disease (AHPND) (http://enaca.org/modu;es/library/publi cation. php?publication_id+1128)

Koiwai, K., Tinwongger, S., Nozaki, R., Kondo, H., Hirono, I. 2016. Detection of acute hepatopancreatic necrosis disease strain of Vibrio parahaemilyticus using loop-mediated isothermal amplification. J. Fish Di, 39, 603-606.

Lightner, D.V. 2014. Documentation of a unique strain of Vibrio parahaemolyticus as the agent of early mortality syndrome (EMS) or acute hepatopancreatic necrosis disease (AHPND) affecting penaeid shrimp with notes on the putative toxins. 9th symposium on diseases in Asian Aquaculture, Ho Chi Minh City, Vietnam.

Liu, Z., Zhang, Q.-L., Wan, X.-Y., Huang, J., 2015. Development of real-time PCR assay for detection of microsporidian Enterocytozoon hepatopenaei and detection in shrimp samples under different growth rates. Prog. Fish. Sci. (in press, in Chinese, English Abstract).

Mastan, S.A. 2-015. Incidences of white feces syndrome (WFS) in farm-reared shrimp Litopenaeus vannamei, Andhra Pradesh. Indo American Journal of Pharmaceutical Research. 5 (09).

MPEDA, 2015. The Marine Products Export Development Authority. www.mpeda.gov.in.

Poulos, B.t., Lightner, D.V. 2006. Detection of infectious myonecrosis virus (IMNV) of penaeid shrimp by reverse -transcriptase polymerase chain reaction (RT-PCR). Dis. Aquat. Organ. 73, 69-72. 
Puthawibool, T., Senapin, S., Kiatpathomchai, W., Flegel, T.W. 2009. Detection of shrimp infectious myonecrosis virus by reverse transcription loop-mediated isothermal amplification combined with a lateral flow dipstick. J. Virol. Tmethods 156, 27-31.

Rajendran, K.V., Shivam, S., Praveeena, P.E., Rajan, J.J.S., Kumar, T.S., Avunje, S., Jagadeesan, V., Babu, P.S.V.A.N.V., Pande, A., Krishnan, N., Alavandi, S.V., Vijayan, K.K. 2016. Emergence of Enterocytozoon hepatopenaei (EHP) in farmed Penaeus (Litopenaeus) vannamei in India. Aquaculture 454, 272-280.

Seibert, C.H., Borsa, M., Rosa, R.D., Cargnin-Ferreira, E., Pereira, A.M.L., Grisard, E.C., Zanetti, C.R., Pinto, A.R. 2010. Detection of major capsid protein of infectious myonecrosis virus in shrimps using monoclonal antibodies. J. Virol. Methods 169, 169-175.

Senapin, S., Phewsaiya, K., Briggs, M., Flegel, T.W. 2007. Outbreaks of infectious myonecrosis virus (IMNV) in Indonesia confirmed by genome sequencing and use of an alternative RT-PCR detection method. Aquaculture 266, 32-38.

Soto-Rodriguez, S.A., Gomez-Gil, B., Lozano-Olvera, R., BetancourtLozano, M., Morales-Covarrubias, M.S. 2015. Filed and experimental evidence of Vibrio parahaemolyticus as the causative agent of acute hepatopancreatic necrosis disease (AHPND) of cultured shrimp Litopenaeus vannamei) in northwestern Mexico. Appl. Environ. Microbiol. 81, 1689-1699.

Sriurairatana, S., Boonyawiwat, V., Gangnonngiw, W., Laosutthipong, C., Hiranchan, J. 2014. White Feces Syndrome of Shrimp Arise from
Transformation, Sloughing and Aggregation of Hepatopancreatic Microvilli into Vermiform Bodies Superficially Resembling Gregarines. PLoS One. 9(6), e99170.

Suebsing, R., Prombun, P., Srisala, J., Kiatpathomchai, W., 2013a. Loop mediated isothermal amplification combined with colorimetric nanogold for detection of the microsporidian Enterocytozoon hepatopenaei in penaeid shrimp. J. Appl. Microbiol. 114, 1254-1263.

Suebsing, R., Prombun, P., Kiatpathomchai, W. 2013b. Reverse transcription loopmediated isothermal amplification (RT-LAMP) combined with colorimetric gold nanoparticle (AuNP) probe assay for visual detection of Penaeus vannamei nodavirus (PvNV). Lett. Appl. Microbiol. 56, 428-435.

Tang, K.F.J., Hana, J.E., Aranguren, L.F., White-Noble, B., Schmidt, M.M., Piamsomboon, P., Risdiana, E., Hanggono. 2016. Dense populations of the microsporidian Enterocytosoon hepatopenaei (EHP) in feces of Penaeus vannamei exhibiting white feces syndrome and pathways of their transmission to healthy shrimp. J. Invert. Pathol. 140, 1-7.

Tang, K.F., Pantoja, C.r., Poulos, B.T., Redman, R.M., Lighner, D.V. 2005. In situ hybridization demonstrates that Litopenaeus vannamei, L. stylirostris and Penaeus monodon are susceptible to experimental infection with infectious myonecrosis virus (IMNV). Dis. Aquat. Organ. 63, 261-265.

Tang, K.F.J., Pantoja, C.R., Redman, R.M., Han, J.E., Tran, L.H., Lightner, D.V. 2015. Development of in situ hybridization and PCR assays for the detection of Enterocytozoon hepatopenaei (EHP), a microsporidian parasite infecting penaeid shrimp. J. 
Invert Pathol. 130. 37-41.

Tang, K.F.J., Pantoja, C.R., Redman, R.M., Lightner, D.V. 2007. Development of in situ hybridization and RT-PCR assay for the detection of a nodavirus (PvNV) that causes muscle necrosis in Penaeus vannamei. Dis. Aquat. Org. 75, 183-190.

Tang, K.F.J., Pantoja, C.R., Redman, R.M., Navarro, S.A. and Lightner, D.V. (2011) Ultrastructural and sequence characterization of Penaeus vannamei nodavirus (PvNV) from Belize. Dis. Aquat. Organ. 94, 179-187.

Tangprasittipap, A., Srisala, J., Chouwdee, S., Somboon, M., Chuchird, N., Limsuwan, C., Srisuvan, T., Flegel, T.W., Sritunyalucksana, K., 2013. The microsporidian Enterocytozon hepatopenaei is not the cause of white feces syndrome in whiteleg shrimp Penaeus (Litopenaeus) vannamei. BMC Vet. Res. 9, 139-148.
Tran, L.H., Nuvan, 1., Redman, R.M., Mohney, L.L., Pantoja, C.R., Fitzsimmons, K., Lightner, D.V. 2013. Determination of the infectious nature of the agent of acute hepatopancreatic necrosis syndrome affecting penaeid shrimp, Dis. Aquat. Organ. 105, 4555.

Velmurgugan, S., Palanikumar, P., Velayuthani, P., Donio, M.B.S., Michael Babu, M., Lelin, C., Sudhkar, S., Citarasu, T. 2015. Bacterial white patch disease caused by Bacillus cereus, a new emerging disease in semi intensive culture of Litopenaeus vananmei. Aquaculture. doi:10.1016/j.aquaculture. 2015.03.017.

Walker, P.J., Winton, J.R. 2010. Emerging viral diseases o fish and shrimp. Vet. Res. 41(6), 51.

\section{How to cite this article:}

Suguna, T. 2020. Disease Diagnosis Prevention and Control of Diseases in L. vannamei. Int.J.Curr.Microbiol.App.Sci. 9(09): 764-776. doi: https://doi.org/10.20546/ijcmas.2020.909.096 